Seyahat ve Otel İşletmeciliği Dergisi/

Journal of Travel and Hospitality Management

16 (3), 2019, 398-417.

Gönderim Tarihi:05.07.2019

Kabul Tarihi:03.09.2019

\title{
Çevre Endişesi, Çevresel Fedakârlık, Normlar ve Yer Tutumunun Çevre Dostu Davranışa Etkisi: Kapadokya/Göreme Milli Parkı Örneği ${ }^{\star}$
}

\author{
Effects of Norms, Place Attachment, Environmental Concerns and Altruism on \\ Environment Friendly Behavior and Purchasing: The Case of Cappadocia/Goreme \\ National Park
}

\author{
Doç. Dr. Lütfi ATAY \\ Çanakkale Onsekiz Mart Üniversitesi \\ Turizm Fakültesi \\ E-posta: lutfiatay@yahoo.com
}

\author{
Dr. Öğr. Gör. Yasin SOYLU \\ Çanakkale Onsekiz Mart Üniversitesi \\ Ayvacık Meslek Yüksekokulu \\ E-posta: yasinsoylu@comu.edu.tr
}

\author{
Dr. Öğr. Üy. Sinan GÖKDEMiR \\ Çanakkale Onsekiz Mart Üniversitesi \\ Turizm Fakültesi \\ E-posta: sinangokdemir@comu.edu.tr
}

$\overline{O Z z}$

Doğal destinasyonlarda yapılan rekreatif faaliyetler çevresel sorunları ve çevre sorunlarını azaltma çabalarını etkileyebilmektedir. Özellikle bireylerin farklı değerlere ve kaynaklara sahip alanlara ziyaretleri, kişinin hem kendisi hakkındaki görüşlerini hem de dünyaya bakış açısını etkilemektedir. Bu durum bireylerin davranışlarında da görülebilmektedir. Çalışmanın evrenini, Göreme Milli Parkına gelen ve sıcak hava balon etkinliğine katılan rekreasyoncular oluşturmaktadır. Bu çalışmanın örneklemini Kapadokya/ Göreme Milli Park'ına gelen ve sıcak hava balonuna binen rekreasyoncular $(n=386)$ oluşturmaktadır. Çalışmada rekreasyoncuların çevre endişeleri, çevresel fedakârlıkları, sübjektif ve kişisel normları ve yer tutumu algıları ile çevre dostu davranışları ve çevreci satın alma davranışları arasındaki ilişkiler incelenmiştir. Araştırma hipotezlerini test etmek için Kısmi En Küçük Kareler Yapısal Eşitlik Modeli (PLS-SEM) kullanılmıştır. Bulgular, rekreasyoncuların sübjektif normları ve çevresel fedakârlıklarının çevre dostu davranışı önemli ölçüde etkilediğini göstermiştir. Ayrıca, rekreasyoncuların çevreci satın alma davranışlarının önemli bir bölümünü, günlük yaşamlarındaki çevre dostu davranışları açıklayabilmektedir.

Anahtar Kelimeler: Çevre endişesi, Çevresel Fedakârlık, Normlar, Yer Tutumu, Çevre Dostu Davranış, Çevreci Satın Alma Davranışı

\section{Abstract}

Recreational activities in natural destinations can affect environmental and environmental efforts. Especially the visits of individuals to areas with different values and resources may affect the individual's view of herself and her view of the world. This can be seen in the behavior of individuals. The population of the study is the recreators who came to Göreme National Park and participated in the hot air balloon event. The study was applied to the recreationists ( $\mathrm{n}: 386)$ who visits Cappadocia / Göreme National Park and experiences a hotair balloon riding. In this study, the relationship between recreation concerns, environmental sacrifices, subjective - individual norms, perception of place attitude and environment-friendly behaviors, environmental purchasing behaviors were examined. Partial Least Squares Structural Equation Model (PLS-SEM) was used to test the research hypotheses. The findings showed that the subjective norms and environmental sacrifices of recreators significantly affect environmentally friendly behavior. In addition, a significant portion of the recreational purchasing behavior of recreators can explain environmentally friendly behaviors in their daily lives.

Key Words: Environmental concerns, environmental altruism, norms, place attachment, environmentfriendly behavior, environment-friendly purchasing.

*Bu çalışma COMÜ BAP birimince desteklenmiş ve doktora tezi verilerinden üretilmiştir. 


\section{Giriş}

19. yüzyıl sonlarında başlayan ve günümüzde her geçen gün etkinliğini arttıran teknolojik gelişmeler ve ülkelerin sürekli büyüme isteği, toplumların etkileşime geçtikleri fiziksel çevrede her geçen gün büyük değişimler yaşanmasına sebep olmuştur (Atay and Dilek, 2013:203). Özellikle endüstrileşme ve kentleşmeyle birlikte metropol şehirlerin ortaya çıkması fiziksel çevre üzerindeki değişimleri hızlandırmıştır. Bu durum, canlıların yaşam standartlarını ve doğal bölgelerin ekolojisini olumsuz yönde etkilemiştir. Yoğun iş temposu altında bu alanlara sıkışmış bireyler sağlıksız ortamlara maruz kalarak, doğal çevre ile olan ilişkilerini gözden geçirmeye başlamışlar ve çevreye yönelik koruma-kullanma davranışlarını düzeltme noktasında kendilerini zorunlu hissetmişlerdir (Mansuroğlu, 2002). Bu, bir nevi kişilerin çevre kullanımlarına yönelik öz eleştiri yapmalarına olanak sağlamıştır.

Buhalis'in (2000:97) ürün, hizmet ve deneyimlerin bir karışımı olarak tanımladığı turistik destinasyonlar, bireylerin iş ortamının yoğunluğundan ayrılarak dinlenmelerine ve stres atmalarına olanak sağlamaktadır. Ancak çoğu zaman bireylerin uzun bir tatil planı yapma fırsatları bulunmamaktadır. Bu nedenle bireyler kendine yakın, ancak doğa temelli ve doğal kaynakları deneyimledikleri alanları tercih edebilirler. Bireylerin doğa ile etkileşime geçerek bedensel ve ruhsal olarak dinlenmelerine olanak veren ve uluslararası piyasada önemi artmaya başlayan açık hava rekreasyon faaliyetleri öncelikle ormanlar, tahrip edilmemiş doğa parçaları, akarsular, doğal yaşam parkları ve doğallığını koruyabilmiş alanlarda gerçekleştirilmektedir (Arni ve Khiaril, 2013:58; Bell ve diğ., 2007:5).

Özellikle, bu tür doğal kaynaklarla etkileşime giren rekreasyoncular çevresel sorunları fark edebilir, bu sorunlara yönelik bir tepki gösterebilir ve çevresel sorunlara yönelik kişisel etkilerini azaltmaya ilişkin bir tutum sergileyebilirler. Bu açıdan turizm faaliyetine ve doğada yapılan rekreatif etkinliklere katılan kişilerin çevre sorunlarına karşı tutumları, etkinlik sırasındaki ve günlük yaşantılarındaki çevreci davranışlarının anlaşılması son derece önemlidir.

\section{Literatür}

Çevre dostu turizm davranışları, ziyaretçilerin doğaya dayalı destinasyonlardaki davranışlarının incelenmesinde önemli bir unsur olarak kabul edilmektedir. Ayrıca, tüketicilerin davranışlarından kaynaklanan çevresel turizm davranışları, turistlerin çevre dostu turizm ürünü satın alma davranışları olarak tanımlanmaktadır (Song ve diğ., 2012). Literatürde yer alan araştırmalardaki yazarlar, çevre dostu davranışı açıklamak için farklı bakış açısı getirmişlerdir. Dolnicar (2006), doğaya dayalı destinasyonlarla etkileşime giren turistlerin, doğal kaynakları korumak ve tatillerinde çevreyi koruyan bir şekilde hareket etmek istediklerini belirtmişlerdir. Crouch ve diğ. (2005), bu tür hassasiyetleri olan turistlerin, bozulmamış çevreleri koruma çabalarında büyük rol oynadıklarını vurgulamıştır. Lee ve diğ. (2013), özellikle çevre turizmi davranışları olan turistlerin, belirli varış yerlerdeki ziyaretçi zararlarını azaltmak için daha fazla çaba sarf ettiğine dikkat çekmiştir. Son olarak, Chiu ve diğ. (2014) bu tür turistlerin davranışlarını daha genel bir çerçevede değerlendirmiş ve turistlerin çevreye karşı sorumlu davranışlarının ekolojik çevreye zarar vermekten kaçınmaya yardımcı olduğunu bildirmiştir.

Ziyaretçilerin seyahatlerini planlarken ve seyahatleri sırasında sergileyecekleri davranışların kişisel faktörlerden ve yakın çevresinden etkilenmesi söz konusudur. Bu 
açıdan çalışmada, doğal destinasyona gelen rekreasyoncuların çevreye yönelik davranışları incelenirken bu unsurlar üzerinde de durulması gerekmektedir. Sübjektif normlar ve kişisel normlar olarak ifade edilen bu kavramlar kişilerin çevre ile etkileşimlerinde bireyin kararlarını etkilemektedir. Sübjektif norm; davranışı gerçekleştirmek veya gerçekleştirmemek için algılanan sosyal baskı olarak tanımlanmaktadır (Ajzen, 1991:187). Başka bir deyişle, bireyin birlikte yaşadığı (aile, akraba, yakın arkadaş ve iş arkadaşları vb.) kişilerin bireyin karar verme sürecine etki etmesi anlamına gelmektedir (Park, 2000:163). Birey, görüşüne değer verdiği bu kişilerin, yapacağı davranışı onaylayıp onaylamama durumuna göre davranışı gerçekleştirme veya gerçekleştirmeme kararını vermektedir (Conner ve Armitage, 1998:1431 ve Park, 2000:163). Hatta bazen, birey bu davranışı fark edilmeyecek şekilde bile yapabilir (Yuzhanin ve Fisher, 2016:137). Sübjektif norm Fishbein ve Ajzen tarafından geliştirilen gerekçeli eylem teorisindeki iki boyuttan biridir. Teoriye göre sübjektif norm gerçek davranışı büyük ölçüde belirleyen davranışsal niyetin sosyal boyutunu oluşturmaktadır (Martin ve diğ., 2011:47). Pek çok araştırma, kişinin bir davranışa yönelik tutumlarının ve sübjektif normlarının davranışı etkilediğini ve davranışsal niyetin belirleyicilerinden biri olduğunu göstermiştir (Chan ve Lau, 2002; Kim ve Han, 2010; Song ve diğ., 2012; Yadav ve Pathak, 2017). Bu çalışmalar, sübjektif normlar ve bireylerin davranışı arasında bir ilişki olduğunu göstermektedir.

Schwartz (1977), çalışmasında kişisel normları; içselleştirilmiş değerlere dayanan kişinin kendi beklentileri olarak tanımlamıştır (Zhang ve diğ., 2014:133). Bu değerleri içselleştirmiş bireyler, değerlerine sadık kalır ve herhangi bir davranış sergilerken bu duygular onların çeşitli sorumluluklar üstlenmelerini sağlar. Çevresel eylemin gerçekleştirilmesinde etkisi olan kişisel normlar, çevresel koşulların bireyler tarafından tehdit edildiği ve bireylerin bu tehdidi ortadan kaldırmak için harekete geçirileceği inançları vasıtasıyla etkinleştirilmektedir (Stern, 2000:413). Bireylerin davranışlarının etkilenmesi için öncelikle kişisel normlarının harekete geçirilmesi gerektiğini belirtmiştik. Harland ve diğ. (1999:2507) bu hareketin (a) kişinin başkalarının refahı için davranışının sonuçlarını fark etmiş olduğu ve (b) kişinin bu sonuçlardan en azından birkaç sorumluluk üstlendiği durumlarda ortaya çıkabileceğini ifade etmiştir. Ancak bu koşullar sağlandığında, bireylerin kişisel normları vasıtasıyla çevreye olan davranışlarının etkilenebileceğini ifade edebiliriz. Özetle, kişisel normlar, çevre dostu davranışların güçlü bir öngörücüsüdür ve etkinleştiriciler aracılığıyla etkinleştirilmeleri gerekmektedir. Buna göre, mevcut çalışma aşağıdaki hipotezleri ortaya koymaktadır;

$\mathbf{H}_{1}$ : Rekreasyoncuların sübjektif normları, çevre dostu davranış üzerinde etkilidir.

$\mathbf{H}_{2}$ : Rekreasyoncuların kişisel normları, çevre dostu davranış üzerinde etkilidir.

Yer tutumu, bireylerin çevre dostu davranış sergileme eğilimini olumlu yönde etkilemektedir. Literatürde, bu etkileşimlerin kişilerin doğaya ilişkin algılarını ve sorunlara karşı çözüm üretme tutum ve davranışları nasıl etkilediğine dair de az sayıda çalışma tespit edilmiştir.

Yer tutumu, doğal bir kaynağa yönelik duygusal bir bağ oluşturan veya mevcut bağı zenginleştiren, bu bağın oluşmasını sağlayacak çeşitli özelliklerin varlığı söz konusu olduğunda ortaya çıkmaktadır (Vaske ve Kobrin, 2001:17). Yer tutumu kavramına ilk olarak Altman ve Low 1992 yılındaki yapmış oldukları çalışmada değinmiş ve yer tutumunu; mekânlar ve insanlar arasında gerçekleşen duygusal bir bağ olarak açıklamıştır (Manzo ve Perkins, 2006:337). Wright ve Howes (2010:271) bu bağın kişi ve/veya gruplar ile bir ev veya mahalle gibi kişilerin yaşadıkları yer ya da 
ziyaret edilen tanıdık destinasyonlar ile kurulabileceğini ifade etmektedirler. Araştırmalar özellikle doğal destinasyonlarda yer tutumunun, Brownlee ve diğ. (2015) 'rekreasyoncular' (rekreatif faaliyetlere katılan kişi) olarak ifade ettiği bireylerin koruma öncesi davranışlarını ve tutumlarını önemli ölçüde etkileyebileceğini ortaya koymaktadır (Kyle ve diğ., 2003; Budruk ve diğ., 2009; Halpenny, 2010; Brownlee ve diğ., 2014). Örneğin, Bricker ve Kerstetter (2000) ABD'deki en popüler akarsu rekreasyon nehri olan South Fork'u ziyarete gelen rekreasyoncuların, bu bölgede bulunan kaynak koşullarına yönelik potansiyel tehditlere karşı duyarlı olduklarını ortaya koymuştur. Halpenny (2010) Kanada'daki Point Pelee Ulusal Park'ındaki ziyaretçilere yönelik yaptığı çalışmada, yer tutumunun çevresel önlemlere yönelik tahminler geliştirebileceğini tespit etmiştir. Son olarak Brownlee ve diğ. (2014) Amerika'da Hartwell Gölüne ziyarete gelen göl rekreasyoncuların yer tutumlarının iklim değişikliği, kuraklık endişeleri ve ziyaretçilerin su koruma tutumları arasında bir ilişki sağladığını tespit etmişlerdir.

Kavramsal ve deneysel araştırmalar, yer tutumunun tipik olarak iki boyutla tanımlandığını göstermiştir. Bu boyutlar "yer bağımlılığı" ve "yer kimliği" olarak ifade edilmiştir (Williams ve diğ., 1992:31; Kyle ve diğ., 2003:34; Williams ve Vaske, 2003:831). Korpela ve diğ. (2009:95) bireylerin sevdikleri yerlere ve yer tutumlarına yönelik ve on aylık periyodik şekilde kararlııklarını belirlemek için yaptıkları çalışmada, kişilerin daha çok "gözde" olabilecek doğal yerleri aradıklarını ve bunun temininde ve aralarındaki duygusal bağın oluşturulmasında "yer tutumu" ve "yer kimliği"nin önemli olduğu sonucuna varmışlardır. Buna göre, mevcut çalışma aşağıdaki hipotezleri ortaya koymaktadır; etkilidir.

$\mathbf{H}_{3}$ : Rekreasyoncuların yer tutumu algıları, çevre dostu davranış üzerinde

Çevresel endişe, bireylerin çevrenin korunmasına yönelik güçlü ve olumlu tutumlarını ifade etmektedir (Minton ve Rose, 1997). Mostafa (2009), çevresel endişenin bireylerin sorunu hafifletmeye ve davranışsal uygulamaları değiştirmeye yönelik motivasyonlar üzerinde önemli bir etkisi olabileceğini belirtmiştir. Ayrıca, çevresel endişe, bireyin motivasyon ve bilişsel durumunu yansıttığı için, çevrenin korunmasına yönelik araştırmalar çevresel endişeyi anlamamızı da sağlayabilir (Mostafa ve Al-Hamdi, 2016). Schwartz, çevresel fedakârlığı, bireyin başka bir birey veya çevrenin zararlı sonuçlarını tanıyarak değiştirmek için bireyin sergilediği sorumlu çevresel davranış olarak tanımlamıştır (Schwartz, 1977). Fedakârlık, bir insanın çevresel, tarihi ve kültürel kaynakları veya rekreasyon olanaklarını korumak ve sürdürmek için bazı şeyleri feda etmeye istekli olmasıdır (Knetsch ve Var, 1976).

Doğaya dayalı rekreasyon faaliyetlerine katılan kişilerin ziyaretlerini tekrarlama isteği göstermeleri, keyif almaları ve o alana özgü kaynakları daha fazla önemsemeleri önemlidir (Ballantyne ve diğ., 2008:440-441). Doğa temelli rekreasyoncuların tek bir alana yönelik tekrarlanan ziyaretleri, katılımcıların o alana yönelik duygusal ve bilişsel bağ kurduklarını göstermektedir (Hammitt ve diğ., 2009:59). Doğal kaynaklarla etkileşime giren rekreasyoncular çevresel sorunları fark edebilir, bu sorunlara yönelik bir tepki gösterebilir ve çevresel sorunlara yönelik kişisel etkilerini azaltmaya ilişkin bir tutum sergileyebilirler.

Konu ile ilgili sosyal bilimler teorilerine bakıldığında, kişinin diğerlerinden farklı özelliklere sahip ortamlarla etkileşiminin, genellikle kişinin kendisi veya dünya görüşü hakkındaki bireysel ve kolektif algı ve tutumlarını etkilediğini ortaya koymaktadır (Brownlee, 2012:7). O halde bu ilişki sayesinde, herhangi bir rekreatif faaliyete katılan 
kişilerin günlük yaşamındaki çevresel sorunlara yönelik de bir takım tutum değişikliklerine gidebileceği öngörülmektedir. Buna göre, mevcut çalışma aşağıdaki hipotezleri ortaya koymaktadır: etkilidir.

$\mathbf{H}_{4}$ : Rekreasyoncuların çevresel endişeleri, çevre dostu davranış üzerinde etkilidir

$\mathrm{H}_{5}$ :Rekreasyoncuların çevresel fedakârlıkları, çevre dostu davranış üzerinde

$\mathbf{H}_{6}$ : Rekreasyoncuların çevre dostu davranışı, çevreci satın alma davranışı üzerinde etkilidir.

\section{Şekil 1: Teorik Model ve Hipotezler}

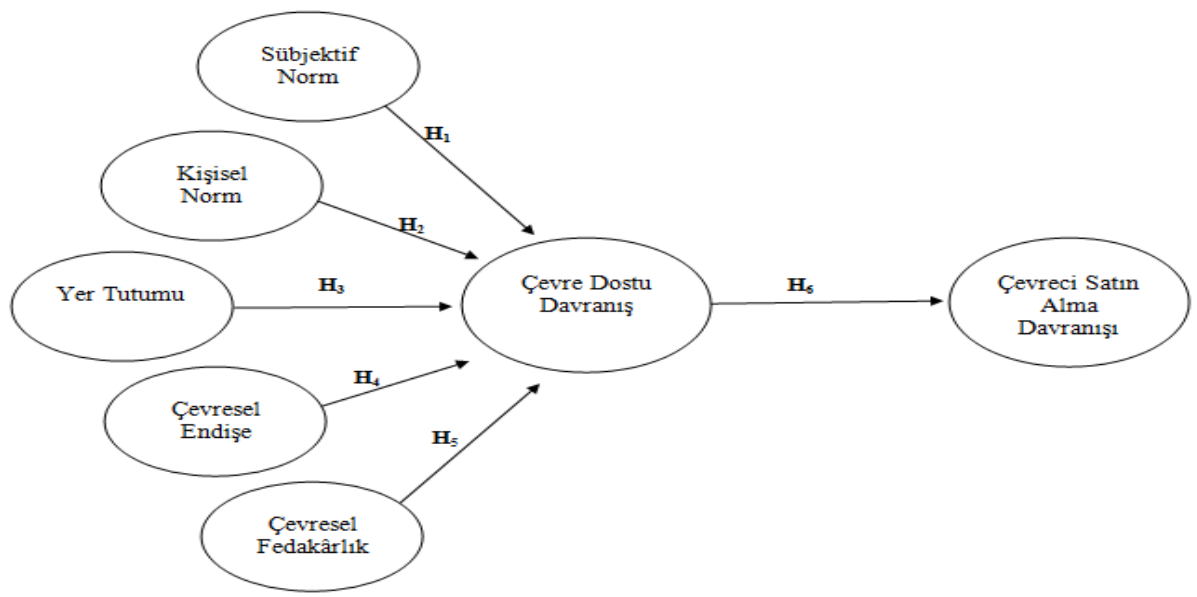

\section{Araştırmanın Yöntemi}

$\mathrm{Bu}$ çalışmanın uygulama alanı, doğal kaynakları nedeniyle bir turizm cazibe merkezi olarak kabul edilen Göreme Milli Parkıdır. Çalışmanın amacı, Göreme Milli Parkı'na gelen ve balona binen rekreasyoncuların çevre dostu davranış ve çevreci satın alma davranışlarının belirlenmesidir.

Çalışma, yer tutumu, sübjektif normlar, kişisel normlar, çevresel endişe ve çevresel fedakârlığın çevre dostu davranışlar ve çevreci satın alma davranışları üzerindeki etkilerini ölçmek için tasarlanmıştır. Araştırma nicel araştırma yöntemi kullanılarak yapılmıştır. Alandaki veriler, anket tekniği ile toplanmıştır. Veri toplama aracı olarak üç bölümden oluşan bir anket uygulanmıştır. Birinci bölümde, kalıcı ikamet ettikleri ülke, cinsiyet, yaş, medeni durum, gelir ve eğitim düzeyi gibi demografik bilgilere ulaşmayı hedefleyen demografik sorular sorulmuştur. İkinci bölümde beş ölçekten oluşan sorular kullanılmıştır. Bunlar; Brownlee ve diğ. (2015) yer tutumu (dokuz ifade), Zhang ve diğ. (2014) kişisel norm (dört ifade), Kim ve Han (2010) tarafından kullanılan sübjektfi norm (üç ifade), Dunlap ve diğ. (2000)'un çevresel endişe (beş ifade) ve Davis, Le ve Coy (2011)'un kullandığı çevresel fedakârlık (beş ifade) ölçekleri kullanılmıştır. Üçüncü bölümde ise, iki ölçekten oluşan; Miller ve diğ. (2015) çalışmalarında yer alan çevre dostu darvanış (onbir ifade) ve Rubright (2014), Yadav ve Pathak (2017)'ın araştırmalarındaki çevreci satın alma davranış ölçekleri (sekiz ifade) yer almaktadır. Ölçeklerdeki ifadeler, bu alanda uzman akademisyenler 
tarafından incelenmiş ve ilgili iyileştirmeler bu akademisyenlerin önerileri sonucunda yapılmıştır. Araştırma için oluşturulan ankette beşli Likert tipi ölçek, (1) Kesinlikle Katılmıyorum ve (5) Kesinlikle Katılıyorum aralığında kullanılmıştır.

Çalışmanın evrenini, Göreme Milli Park'ına gelen ve sıcak hava balon etkinliğine katılan rekreasyoncular oluşturmaktadır. Araştırmanın örneklemi ise, olasılığa dayalı olmayan örnekleme yöntemlerinden biri olan kolayda örnekleme (convenience sampling) yöntemi ile elde edilmiştir. Bölgede bu etkinliğe katılan yaklaşık 500 kişiye 2018 yılı Nisan ve Ekim ayları arasında anket formları dağıtılmıştır. Geri dönüş sağlanan 420 anket arasından kullanılabilir olan 386 anket çalışmanın örneklemini oluşturmuştur.

Çalışmada hipotezler kısmi en küçük kareler (PLS) analizi kullanılarak, yapısal eşitlik modellemesi ile test edilmiştir. Model oluşturmak ve geçerliliğini değerlendirmek için SmartPLS (V.3.2.6) yazılımı kullanılmıştır (Ringle ve diğ., 2015). PLS, yapısal modellerde yol katsayılarını tahmin etmek için iyi bilinen bir tekniktir. Dahası, PLS son on yıl boyunca gizli araştırmaları normal olmayan şartlar altında küçük-orta örneklem örnekleriyle modelleme kabiliyeti nedeniyle giderek daha popüler hale gelmiştir (Rezaei ve Ghodsi, 2014). Gizli yapılı bir yapısal denklem modeli iki bileşene sahiptir. Illk bileşen yapısal modeldir ve PLS-SEM bağlamında iç model olarak adlandırılır (Hair ve diğ., 2011). Dahası, içsel model gözlemlenmemiş veya gizli yapılar arasındaki ilişkileri (yolları) görmemize izin verir (Henseler ve diğ., 2009). Yapısal denklem modelinin ikinci bileşeni, PLS-SEM bağlamında ölçüm modellerini de içeren dış modellerdir (Hair ve diğerleri, 2014). Çalışmaya göre, dış modeller gösterge değişkenleri ile karşılık gelen yapıları arasındaki ilişkileri değerlendirmek için kullanılmaktadır.

\section{Bulgular}

Göreme Milli Park'ında balona binen rekreasyoncuların \%36,4'ünün gelirlerini yüksek ve çok yüksek olarak belirttikleri görülmüştür. 251 kişinin $(\% 65,4)$ eğitim seviyesini üniversite eğitimi ve lisansüstü eğitimi olarak belirtmeleri bir diğer dikkat çekici ayrıntıdır. Bu kategoride yaklaşık beş farklı kıtadan ziyaretçinin olduğunu ve bunların oranının da \%84,4 (Türkiye'de yaşayanlar Avrupa kıtasından çıkarılmıştır) olduğunu söyleyebiliriz. Bu veriye paralel olarak ziyaret sıklığına da baktığımızda, bölgenin ve özellikle balon etkinliğinin özellikli müşterilere hitap etme kapasitesi nedeniyle 'bir kez ziyaret ettim' seçeneğini seçen rekreasyoncuların katılımcıların \%94,7'sini (n: 318) oluşturduğu görülmektedir. Bu değerler alan için en dikkat çekici betimleyici istatistiklerdir. 
Tablo 1: Göreme Alanı Rekreasyoncularının Betimleyici İstatistikleri

\begin{tabular}{|c|c|c|c|c|c|}
\hline Özellik & Frekans $(\mathrm{N})$ & Yüzde (\%) & Özellik & Frekans(N) & Yüzde (\%) \\
\hline Yaș & $\mathbf{N}$ & $\%$ & Gelir & $\mathbf{N}$ & $\%$ \\
\hline $18-25$ & 37 & 9,7 & Düşük & 11 & 2,8 \\
\hline $26-35$ & 149 & 39,4 & Orta & 233 & 60,8 \\
\hline $36-45$ & 142 & 37,5 & Yüksek & 127 & 33,0 \\
\hline 45 ve üzeri & 51 & 13,4 & Çok Yüksek & 13 & 3,4 \\
\hline Toplam & 379 & 100,0 & Toplam & 384 & 100,0 \\
\hline Cinsiyet & $\mathbf{N}$ & $\%$ & Medeni Durum & $\mathbf{N}$ & $\%$ \\
\hline Kadın & 195 & 51,2 & Evli & 192 & 50,8 \\
\hline Erkek & 186 & 48,8 & Bekâr & 186 & 49,2 \\
\hline Toplam & 381 & 100,0 & Toplam & 378 & 100,0 \\
\hline Eğitim & $\mathbf{N}$ & $\%$ & Sürekli Yașanılan Ülke & $\mathbf{N}$ & $\%$ \\
\hline Lise & 37 & 9,6 & Türkiye & 58 & 15,6 \\
\hline Önlisans & 96 & 25,0 & Avrupa & 157 & 42,3 \\
\hline Lisans & 185 & 48,2 & Asya & 88 & 23,7 \\
\hline Lisansüstü & 66 & 17,2 & Avustralya & 36 & 9,7 \\
\hline Toplam & 384 & 100,0 & Güney Amerika & 12 & 3,2 \\
\hline Ziyaret Sayısı & $\mathbf{N}$ & $\%$ & Kuzey Amerika & 20 & 5,5 \\
\hline 1 & 318 & 94,7 & Afrika & - & - \\
\hline 2 & 16 & 4,7 & Antartika & - & - \\
\hline $3 \mathrm{ve}+$ & 2 & 0,6 & Toplam & 371 & 100,0 \\
\hline Toplam & 336 & 100,0 & & & \\
\hline
\end{tabular}

\section{1. Ölçüm Modelinin Değerlendirilmesi}

Ölçüm modeli değerlendirmesine geçmeden önce, ölçüm modelindeki yapının yansıtıcı mı yoksa biçimlendirici mi olduğunu değerlendirmek için yapılar ve göstergeler arasındaki ilişki analiz edilmiştir (Diamantopoulos ve Siguaw, 2006; Stacie ve diğ. 2007). Bu çalışmada, Jarvis ve ark. (2003), yansıtıcı yapıların seçimini önermektedir. PLS-SEM değerlendirmesi iki aşamalı bir prosedürden oluşmuştur: ölçüm modeli değerlendirmesi ve bunu takiben yapısal model değerlendirmesi. Tablo 2, yansıtıcı yapılar için göstergelerin dış yüklerini göstermektedir. 
Tablo 2: Maddelerin, Yapıların ve Ölçüm Modelinin Değerlendirilmesi

Değişkenler/ifadeler

$\bar{X}$

Yük

Değeri

Kişisel Norm:a: 0.897; CR: 0.927; AVE: 0,761

İnsanların yerel ortama zarar vermesini engellemek zorunda olduğumu düşünüyorum.

4.22

0,836

Yerel çevre yasalarına uyma yükümlülüğüm olduğunu düşünüyorum.

4.25

0,885

Yerel çevrenin korunmasına destek olma yükümlülüğüm olduğunu düşünüyorum.

$4.30 \quad 0,877$

Günlük hayatımın neden olduğu yerel çevre sorunlarını hafifletmek zorunda olduğumu düşünüyorum.

$4.18 \quad 0,889$

Yer Tutumu: $\alpha$ : 0.920; CR: 0.933; AVE: 0,607

Kapadokya ile kendimi özdeştiriyorum.

Kapadokya benim için çok önemlidir.

Kendimi Kapadokya'ya bağlı hissediyorum.

Kapadokya'nın balon etkinliği için diğer bölgelerden daha iyi olduğunu düşünüyorum.

$4.16 \quad 0,728$

Balon etkinliği olarak Kapadokya'nın benim için vazgeçilmez olduğunu düşünüyorum.

4.11

0,793

Balon etkinliği olarak en çok tatmin olduğum yerin Kapadokya olduğunu düşünüyorum.

4.17

0,776

Kendimi Kapadokya'yabağlı hissediyorum.

4.00

0,843

Kapadokyadayken, kendimi onun bir parçası gibi hissediyorum.

Kendimi Kapadokya'ya aitmiş gibi hissediyorum.

Çevresel Endişe: $\alpha$ : 0.840; CR: 0.885; AVE: 0,606

Doğanın dengesinin hassas olduğunu ve kolayca bozulabileceğini düşünüyorum.

$4.11 \quad 0,746$ İnsanların çevreyi istismar ettiğini düşünüyorum.

Her şey bugünkü gibi olursa, yakında ekolojik bir felaket yaşanacağını düşünüyorum.

İnsanların yaşamlarını sürdürebilmek için doğayla uyumlu yaşamak zorunda olduğunu düşünüyorum.

Sübjektif Norm: $\alpha$ : 0.775; CR: 0.869; AVE: 0,689

Innsanlar katılığım rekreatif faaliyetlerde çevreye zarar vermeyeceğimi düşünürler.

Düşüncelerine değer verdiğim kişiler rekreatif faaliyetlerde çevre dostu davranmamı tercih ederler.

$4.20 \quad 0,767$

Çevresel Fedakârlık: $\alpha$ : 0.822; CR: 0. 875; AVE: 0,583

Davranışlarım doğal çevreye zarar veriyorsa, bunları yapmaktan vazgeçerim.

Doğal çevrenin korunmasına yardımcı olacak sorumlulukları üstlenmeye hazırım.

Çabalarım için takdir görmesem bile, çevre için bir şeyler yapmaya hazırım.

Her zaman çevre için iyi olduğunu düşündüğüm şeyleri yaparım.

$4.22 \quad 0,801$

Çevreye uygun olanı yapmak için kendi yolumun dışına çıkmaya hazırım.

4.15

0,747 


\section{Tablo 2'nin devamı}

Çevre Dostu Davranış: $\alpha$ : 0.767; CR: 0.841; AVE: 0,516

Atıkları azaltmak için daha az gıda satın alırım.

Çevreci olabilmek için başkalarını teşvik ederim.

Mümkün olduğunca yürümeyi tercih ederim.

Organik gıda ürünleri satın almayı tercih ederim.

Mümkün olduğunca toplu taşıma araçlarını kullanırım.

Çevreci Satın Alma Davranışı:a: 0.905; CR: 0.922; AVE: 0,599

Düzenli olarak çevre dostu ürün satın alırım.

Günlük intiyaç ürünlerim için çevre dostu ürün satın alırım.

Son altı ay içinde çevre dostu ürün satın aldım.

Çevre sorunlarını çözmeye yardım edebileceğimi düşünüyorum.

Çevreye dost ürünleri satın alarak çevreyi koruyabilirim.

Tasarruf sağlayan ürünler satın alırsam doğal kaynakları korumuş olurum.

Çevreye zarar vermeyecek günlük ev eşyaları (bakkaliye veya temizlik ürünleri gibi) satın almaya çalışırım.

Tüm yapılar için iç tutarlılık güvenilirliği, hem Kompozit Güvenilirlik (CR) hem de Cronbach Alpha için önerilen 0.7 eşiğinin üzerinde ve tatmin edicidir. Tüm ölçeklerimiz için Çıkarılan Ortalama Varyans (AVE), 0.5'in eşik değerini aşarak, yeterli yakınsama geçerliliği olduğunu göstermektedir. Bu noktada, Bagozzi ve Yi (1988), AVE değerinin her bir gizli değişken için 0,5 veya daha yüksek olması gerektiğini bildirmiştir. Bu çalışmaya dâhil edilen tüm yapıların, 0.7'nin altında yüklemesi olan ve bu nedenle silinen altı madde dışında önerilen seviyeyi aştığı görülmektedir. Hulland (1999) 0,4 veya 0,5 'ten düşük bir gizli değişken yükün, ölçüm modelinden çıkarılması gerektiğine dair yansıtıcı göstergelerin 0,7'nin altına yükleme yapıldığında yeni geliştirilen ölçek için de kabul edilebilir olduğunu öne sürmektedir. Literatürde gizli değişken yüklerin 0,5 'ten küçük olmaları nedeniyle ölçüm modellerinden çıkarıldığı çalışmalar vardır (Carranza ve Diaz, 2018;Fahmy ve diğ., 2015; Memon ve Rahman, 2014; Molina ve diğ., 2018; Rivera ve diğ., 2018; Sapihis ve diğ, 2015; Sie ve diğ., 2018). Bu çalışmalarda, yazarlar analizlerini oluştururken en azı üç en yükseği on olmak üzere ölçeklerdeki ifadeleri AVE değerini yükseltebilmek için çıkarmışlardır. Ayrıca, bu yazılar yayınlanmadan önce hakemler tarafından incelenmiş ve uluslararası bir dergide yayınlanmıştır.

Veri setinin SmartPls analiz programına yüklenmesi sonrası ortaya çıkan sonuçlar yukarıda Tablo 2'de verilmiştir. Analizin bu aşamasında ölçeklerde Cronbach Alpha ve AVE değerlerini düşüren ifadeler tespit edilmiştir. Bu ifadelerin çıkarılmasına ve dolayısıyla değerlerin yükseltilmesine yönelik bilgiler yukarıda detaylı bir şekilde verilmiştir. Anket formunda, değerlerin düşmesine sebep olan ve çıkarılması gereken ifadeler çevre dostu davranış ölçeğinde altı ifadeden oluşmaktadır. Bunun dışındaki ölçeklerde madde çıkarılması yapılmamıştır. Geriye kalan bu ölçekler hem Alpha katsayısı hem de AVE değeri bakımından yeterli değerleri sağlamıştır. Çevre dostu davranış ölçeğinde altı ifadenin analizden çıkarılması sonucu Alpha değeri 0,767 ve AVE değeri 0,516 olmuştur. 
Yer tutumu ölçeği Cronbach Alpha değeri (a: 0.920)en yüksek ölçektir. AVE değeri en yüksek değere sahip ölçek ise 0,761 ile kişisel norm ölçeğidir. Çevreci satın alma davranışının ( $\alpha$ : 0.905) ve yer tutumu ( $\alpha$ : 0.873) ölçeklerinin Cronbach Alpha değeri 0,90'nın üzerindedir. Kişisel norm ( $\alpha$ : 0.897), çevresel endişe ( $\alpha$ : 0.840)ve çevresel fedakârlık( $\alpha$ : 0.822) ölçeklerinin Cronbach Alpha değerleri 0,80'nin üzerindedir ve bu sonuç bu ölçeklerin yüksek güvenirlilik sağladığını göstermektedir. Yine sübjektif norm ve çevre dostu davranış ölçekleri de 0,70 'in üzerinde sonuçlar vermiştir. Bu da bu ölçeklerin oldukça güvenilir olduğunu göstermektedir.

Ölçeklerin Kompozit Güvenirlik (CR) değerlerine bakıldığında tüm ölçeklerin kompozit değerleri ise 0,80 'nin üzerinde sonuçlar vermiştir. Dahası yer tutumu (CR:0,933), kişisel norm (CR:0,927) ve çevreci satın alma davranışı (CR:0,922) ölçeklerinin Kompozit Güvenirlik (CR) değerleri 0,90'nın üzerindedir. Bu alanda en yüksek CR değeri ise 0,933 ile yine yer tutumu ölçeği için gerçekleşmiştir.

Bir sonraki adım, önlemlerin diğer bazı değişkenlerin bir yansıması olmadığı anlamına gelen ayırt edici geçerliliği değerlendirmekti. "Ayırt Edici Geçerlilik" (Discriminant Validity) başka bir geçerlilik yöntemidir ve bu, ilgi ölçüsü ile diğer yapıların ölçütleri arasındaki düşük korelasyonlarla belirtilmektedir (Ali ve diğ., 2016). $\mathrm{Bu}$ nedenle, çalışmada ayırt edici geçerlilik değerlendirilmiştir. Fornell ve Larcker (1981), her gizli değişkendeki AVE'nin karekökünün, eğer bu değer gizli değişkenler arasındaki diğer korelasyon değerlerinden daha büyükse, ayırt edici geçerliliği sağlamak için kullanılabileceğini öne sürmektedir. Çapraz öğeler (karekök AVE), karşılık gelen satırlar ve sütunlardaki diyagonal olmayan öğelerden daha büyük olduğunda, ayırt edici geçerlilik verilir (Ali ve diğ., 2015). Tablo 3, her bir AVE'nin (köşegen üzerinde gösterilen) karekökünün, bütün yansıtıcı yapılar için yeterli ayırt edici geçerliliği gösteren, yapı korelasyon matrisindeki ilgili yapılar arası korelasyonlardan daha büyük olduğunu göstermektedir. Genel olarak, tüm önlemler tatmin edici güvenilirlik ve geçerlilik göstermektedir.

Tablo 3: "Fornell-Larcker” Ayırt Edici Geçerlilik Kriteri

\begin{tabular}{|c|c|c|c|c|c|c|c|}
\hline Yapilar & $\mathrm{KN}$ & SN & YT & ÇDD & ÇSAD & ÇE & ÇF \\
\hline Kişisel Norm & 0.872 & & & & & & \\
\hline Sübjektif Norm & 0.357 & 0.830 & & & & & \\
\hline Yer Tutumu & 0.449 & 0.474 & 0.779 & & & & \\
\hline Çevre Dostu Davranıș & 0.195 & 0.435 & 0.272 & 0.718 & & & \\
\hline Çevreci Satın Alma Davranıșı & 0.186 & 0.373 & 0.406 & 0.534 & 0.774 & & \\
\hline Çevresel Endișe & 0.514 & 0.545 & 0.396 & 0.263 & 0.204 & 0.779 & \\
\hline Çevresel Fedakârllk & 0.488 & 0.578 & 0.479 & 0.344 & 0.319 & 0.581 & 0.764 \\
\hline
\end{tabular}

Ek olarak, aşağıdaki tabloda ayırt edici geçerliliği değerlendirmek için daha iyi bir araç olarak yakın zamanda ortaya konan Heterotrait Monotrait korelasyon oranı gösterilmiştir (Henseler ve diğ, 2015; Henseler ve diğ, 2016). Bu yeni yöntem kullanılarak ayırt edici geçerlilik test edildi ve sonuçlar Tablo 4'te gösterildi. HTMT değeri 0,90 değerinden büyükse, ayırt edici geçerlilik sorunu vardır. Tablo 3 'te 
degösterildiği gibi, bu yöntemde de tüm değerler, ayırt edici geçerliliğin bir sorun olmadığını belirten HTMT.90'ı geçmiştir.

Tablo 4: “HTMT” Ayırt Edici Geçerlilik Kriteri

\begin{tabular}{lccccccc}
\hline Yapılar & KN & SN & YT & ÇDD & ÇSAD & ÇE & ÇF \\
\hline Kișisel Norm & & & & & & \\
Sübjektif Norm & 0.419 & & & & & \\
Yer Tutumu & 0.494 & 0.549 & & & & \\
Çevre Dostu Davranıș & 0.229 & 0.554 & 0.298 & & & \\
Çevreci Satın Alma Davranıșı & 0.201 & 0.438 & 0.437 & 0.603 & & \\
Çevresel Endișe & 0.604 & 0.671 & 0.441 & 0.319 & 0.227 & \\
Çevresel Fedakârlık & 0.573 & 0.721 & 0.541 & 0.430 & 0.358 & 0.700 & \\
\hline
\end{tabular}

\subsection{Yapısal Modelin Değerlendirilmesi}

Yapısal model ve hipotezleri test etmek için SmartPLS sürüm 3.2.6 kullanılmıştır. Alt yapıların ağırıklarının ve yol katsayılarının istatistiksel önemini incelemek için 1000 yinelemeli önyükleme prosedürü uygulanmıştır (Chin ve diğ. 2008). SmartPLS yazılımı kullanan SEM-PLS yaklaşımı, CB-SEM'deki gibi genel bir model uyumu hakkında geleneksel bir değerlendirme sunmamaktadır (Ali ve diğ., 2015). PLS genel olarak uygunluk indeksleri üretmediğinden, $\mathrm{R}^{2}$ modelin açıklayıcı gücünü değerlendirmenin birincil yoludur (Ali ve diğ., 2016). Bu nedenle, tüm yapıların düzeltilmiş R-karesi, Tenenhaus, Vinzi, Chatelin ve Lauro (2005) tarafından sunulan uygunluk (GoF) endeksi olarak bilinen model uyumunu değerlendirmek için bir tanı aracı kullanmak için hesaplanmıştır. GoF verilerin önerilen modele ne kadar iyi uyduğunu gösterenbir araçtır. Analizde GoF değeri tüm yapıların AVE değerlerinin ortalaması ile R-karenin ortalamalarının çarpımının karekökü alınarak hesaplanmaktadır. Hoffmann ve Brinbrich (2012), GoF analizinin sonuçlarını değerlendirmek için aşağıdaki kesme değerlerini bildirmiştir: GoFsmall $=0.1 ;$ GoFmedium $=0.25$; GoFlarge $=0.36$. Bu çalışmada kullanılan model için 0.470 'lik bir GoF değeri hesaplanmış ve bu da çok iyi bir model uyumu olduğunu göstermektedir. Bununla birlikte, GoF'nin model doğrulama için istatistiksel bir araç olarak kullanılamayacağı dikkat çekicidir. Aksine, toplanan verilerin önerilen modele ne kadar uyduğunu gösteren bir tanı aracıdır (Henseler ve Sarstedt, 2013).

Ölçüm modeli ve uyum iyiliği (GoF) sonrasında, yapısal modeldeki varsayımsal ilişkiler test edilmiştir. Hipotez testlerinin sonuçları Şekil 2'de gösterilmiştir. Şekildeki değerler standartlaştırımış katsayıları ve bunların t-değerlerini göstermektedir. Şekil 2'deki düzeltilmiş $\mathrm{R}^{2}$ 'ler, öngörülen değişkenlerin ilgili yapıdaki açıklayıcı gücüne atıfta bulunmaktadır. Kişisel normlar, yer tutumu, çevresel endişe, sübjektif normlar ve çevresel fedakârlık, çevre dostu davranışların \% 20,4'ünü açıklamaktadır. Ayrıca, çevre dostu davranış, çevreci satın alma davranışının \% 28,6'sını öngörmektedir. Model geçerliliği ile ilgili olarak Chin ve diğ. (2008), endojen gizli değişkenleri sırasıyla 0.67, 0.33 veya $0.19 \mathrm{R}^{2}$ değerlerine dayanarak önemli, orta veya zayıf olarak 
sınıflandırmıştır. Buna göre çevre dostu davranış $\left(R^{2}=0.204\right)$ ve çevreci satın alma davranışı $\left(R^{2}=0.286\right)$ orta olarak tanımlanabilir.

Şekil 2: Yol katsayıları için $\beta$ ve endojen yapılar için $\mathbf{R}^{2}$.

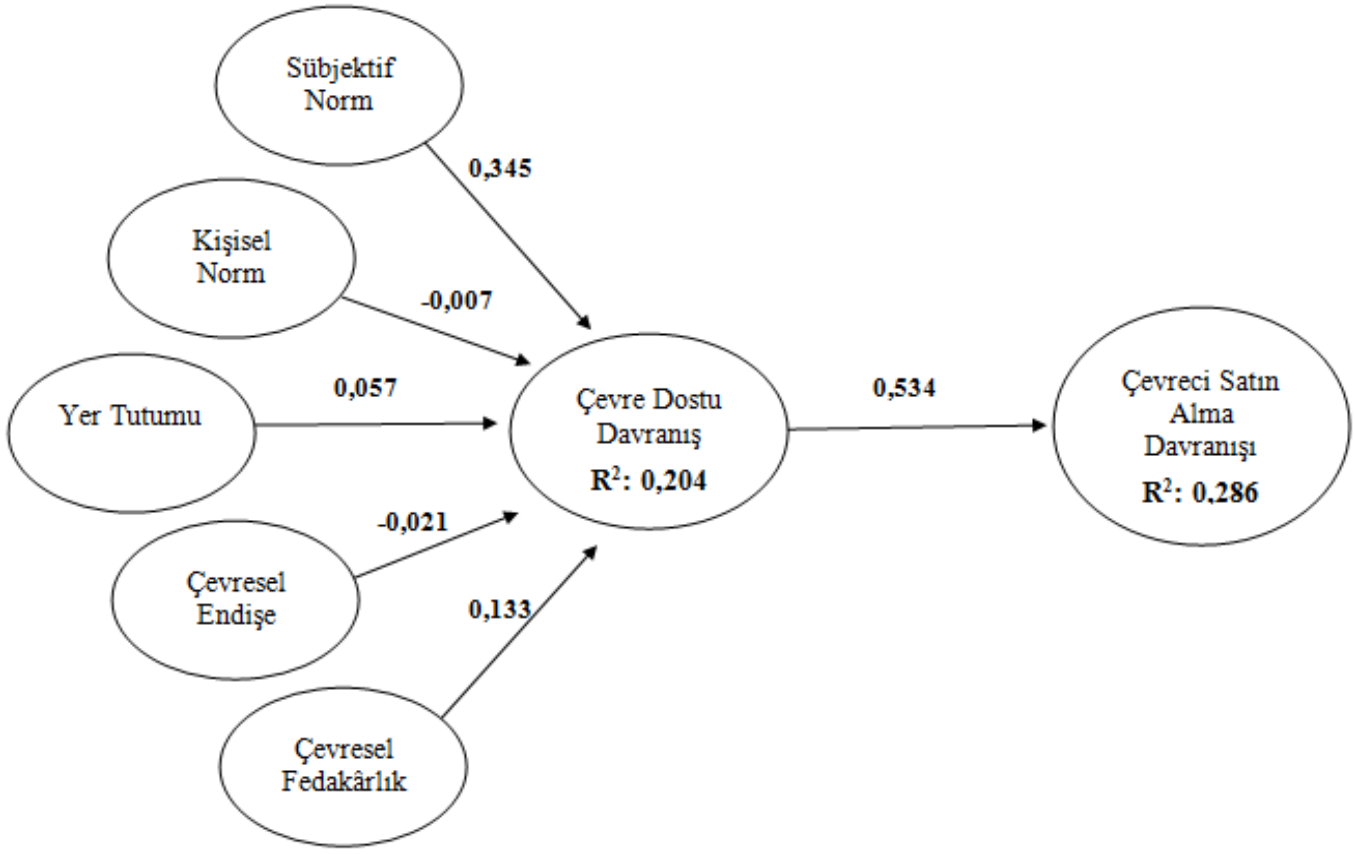

Yapısal modelin ve hipotez testlerinin sonuçları Tablo 5'e verilmiştir. Önyükleme prosedürü, \% 95'lik bir güven aralığında beş yol katsayısının beklediğini göstermektedir. Hipotez 1, sübjektif normların çevre dostu davranışlarla pozitif ilişkili olduğunu ileri sürmüştür. Subjektif normlar göz önüne alındığında, çevre dostu davranışa olumlu ve önemli bir etkisi vardır ( $\beta \mathrm{SN} \rightarrow$ ÇDD $=0.345, \mathrm{p}<0.05$ ). Böylece $\mathrm{H}_{1}$ desteklenmiştir. Hipotez 2 test edildi. Kişisel normlar ve çevre dostu davranış arasındaki ilişkiler anlamlı değildi ( $\beta \mathrm{KN} \rightarrow$ ÇDD $=-0.007, p>0.05)$. Bu nedenle, Hipotez 2 desteklenmemiştir.

3. ve 4. hipotezler, yer tutumu ve çevresel endişenin, çevre dostu davranışlarla pozitif ilişkili olduğunu önermiştir. Bulgular, her iki tahmincinin de çevre dostu davranış üzerinde olumlu ve anlamlı bir etki yapmadığını göstermiştir ( $\beta$ YT $\rightarrow$ ÇDD $=0.057, p$ $>0.05 ; \quad \beta$ ÇE $\rightarrow$ ÇDD $=-0.021, p=744>0.05)$. Böylece, Hipotezler 4 ve 5 desteklenmemiştir.

$\mathrm{H}_{5}$, çevresel fedakarlığın çevre dostu davranışı etkileyeceğini öne süren bir hipotez olarak kurulmuştur. Sonuç $(\beta$ ÇF $\rightarrow$ ÇDD $=0.133, p=05<0.05$ ) hipotezin desteklendiğini ortaya koymaktadır. Son olarak, çevre dostu davranışın çevreci satın alma davranışları üzerinde olumlu ve önemli bir etkisi vardır $(\beta$ ÇDD $\rightarrow$ ÇSAD $=0.534$, $\mathrm{t}=13.972, \mathrm{p}<0.00)$. 
Tablo 5: Model Hipotez İstatistikleri (Önyükleme) ve Endojen Yapı Değerlendirmesi

Yol katsayıları ve ön yükleme

\begin{tabular}{|c|c|c|c|c|c|}
\hline \multicolumn{2}{|c|}{ Hipotezler } & \multirow{2}{*}{ 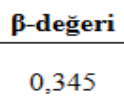 } & \multirow{2}{*}{$\frac{\text { t-değeri }}{5,542}$} & \multirow{2}{*}{$\frac{\text { p-değeri }}{0,000}$} & \multirow{2}{*}{$\begin{array}{l}\text { Sonuç } \\
\text { Kabul }\end{array}$} \\
\hline H1 & Sübjektif Norm $\rightarrow$ Çevre Dostu Davranış & & & & \\
\hline H2 & Kişisel Normlar $\rightarrow$ Çevre Dostu Davranış & $-0,007$ & 0,123 & 0,902 & Ret \\
\hline $\mathbf{H 3}$ & Yer Tutumu $\rightarrow$ Çevre Dostu Davranış & 0,057 & 0,944 & 0,345 & Ret \\
\hline H4 & Çevresel Endişe $\rightarrow$ Çevre Dostu Davranış & $-0,021$ & 0,327 & 0,744 & Ret \\
\hline H5 & Çevresel Fedakârlık $\rightarrow$ Çevre Dostu Davranış & 0,133 & 1,966 & 0,050 & Kabul \\
\hline H6 & Çevre Dostu Davranış $\rightarrow$ Çevreci Satın Alma Davranışı & 0,534 & 13,972 & 0,000 & Kabul \\
\hline \multicolumn{3}{|c|}{ Endojen yapı değerlendirmesi } & $\mathbf{R}^{2}$ & \multicolumn{2}{|c|}{$\begin{array}{c}\text { Düzeltilmiș } \\
\mathbf{R}^{2}\end{array}$} \\
\hline \multicolumn{2}{|c|}{ Çevre Dostu Davranış } & & $\mathbf{0 , 2 0 4}$ & \multicolumn{2}{|c|}{0,194} \\
\hline \multicolumn{2}{|c|}{ Çevreci Satın Alma Davranışı } & & 0,286 & \multicolumn{2}{|c|}{0,284} \\
\hline
\end{tabular}

Çalışmada balon etkinliğine katılan ziyaretçilerin, etkinliğin ana kaynak değeri olan hava doğal kaynağına ilişkin değerlendirmeleri öğrenilmek istenmiştir. Bu amaçla ziyaretçilerin geleneksel turizm unsurlarıyla, günümüzün çevresel sorunlarından biri olan hava kirliliği ile karşılaştırdıklarında hangi yönde bir karar verecekleri araştırma sorularından biri olmuştur. Bunu belirlemeye yönelik ziyaretçilere; seyahat maliyeti, güvenlik, boş zaman, turistik ürün, destinasyonun bilinirliği ve destinasyonun uzaklığı ile hava kirliliğini karşılaştırmaları istenmiştir. Ziyaretçilerin seçim sonuçları ve frekans analizleri Şekil 3’te gösterilmiştir.

\section{Şekil 3: Ziyaretçilerin Geleneksel Turizm Unsurları ve Hava Kirliliği Önceliklerine İlişkin Yanıt Yüzdeleri}

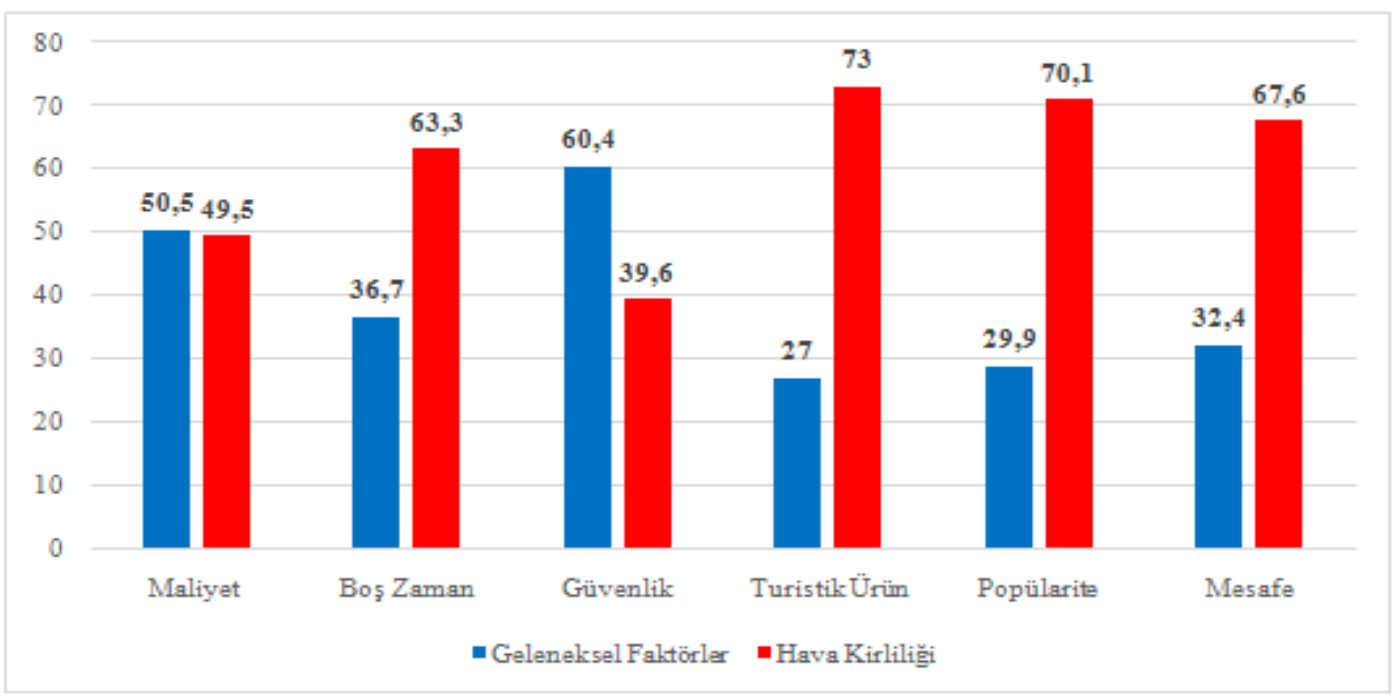


Ziyaretçiler boş zaman, turistik ürün, popülarite ve mesafe de hava kirliliği sorununu öncelikleri olduğu yönünde görüş bildirmişlerdir. Sonuçların \%60'ın üzerinde hava kirliliği lehinde sonuçlanması önemlidir. Bu faktörlerde sadece maliyet ve güvenlik unsuru öncelikli turizm unsurlarından olmuştur. Öncelikle son yıllarda ülkemizin etrafında yaşanan savaş ve bunun yol açtığı sorunlar, her ne kadar istatistiklerde düzelmeler yaşansa da, güvenliğin hala bazı çevresel sorunların çözümünden önce düşünülebildiğini göstermektedir. Bu sorunu ortadan kaldırmaya yönelik ulusal ve uluslararası çözümlerin bir an evvel hayata geçirilmesi ve insanların bu tür kaygılarından uzaklaştırılarak çevresel sorunlara karşı eğilmeleri sağlanabilir. Maliyet ise yaklaşık yarı yarıya (Maliyet $=\% 50,5$, Hava Kirliliği $=\% 49,5$ ) bir sonuç ortaya çıkarmıştır.

Zhang ve diğ. (2016) yapmış oldukları çalışmada hava kirliliğinin bir türü olan "sis" ile geleneksel turizm unsurları arasında benzer bir çalışma gerçekleşmiştir. Bu çalışmada hiçbir kategoride sis kirliliği \%40' geçemememiştir. Hatta sis kirliliğine karşı 'güvenlik' \%86,6 ve 'maliyet' \%71,8 gibi yüksek sonuçlar ortaya koymuştur. Bu durumu araştırmacı ziyaretçilerin karar verme süreçlerinde ilk önce maliyet ve güvenliğin gelmesinden kaynaklandığını belirtmiştir. Her ne kadar, bu açıdan yapılan ilk çalışmalardan biri olmasına ve verilerin geleneksel turizm unsurları tarafına ağırlık kazanmasına rağmen Zhang ve diğ. (2016) yaptığı bu çalışma önemlidir. Göreme Milli Park'ında gerçekleştirilen bu çalışma da ise, rekreasyoncuların güvenlik dışındaki bütün geleneksel turizm unsurlarına karşı hava kirliliğini ön plan tutmaları son derece önemlidir. Hava kirliliği göz önüne alındığında, rekreasyoncular geleneksel turizm unsurlarına dayanan ilk kararlarını, varış yerlerinin hava kalitesine göre değiştirilebilir ya da düzeltilebilir.

\section{Tartışma, Sonuç ve Öneriler}

Çalışmada, Kapadokya bölgesine gelip balon rekreatif etkinliğini kullanan rekreasyoncuların çevre dostu davranışlarının ve çevreci satın almalarının arasındaki ilişki PLS-SEM modeli kullnılarak araştırılmıştır. Önceki araştırmalara dayanarak, araştırma kişisel ve sübjektif normlar, çevresel endişe, yer tutumu, çevresel fedakârlık, çevre dostu davranış ve çevreci satın alma davranışı arasındaki ilişkileri test etmiştir. Sonuçlar, rekreasyoncuların günlük yaşamdaki çevre dostu davranışının ve satın alımlarının belirleyicilerinin anlaşılması için teorik ve pratik sonuçları göstermektedir.

Desteklenen hipotezlerden biri, sübjektif normların, bireylerin günlük yaşamlarındaki çevre dostu davranışları üzerinde önemli bir etkiye sahip olmasıdır. Bireylerin aileleri ve yakınları tarafından etkilenmesi ve çevre sorunlarını çözmek için buna göre hareket etmeleri büyük önem taşımaktadır. Buradaki bulgular, benzer bir konuyu araştıran önceki çalışmaların bulgularıyla doğrulanmaktadır (Chan ve Lau, 2002; Kim ve Han, 2010; Song ve diğ., 2012 ve Yadav ve Pathak, 2017). Kim ve Han (2010) tarafından otel müşterileri üzerinde yapılan araştırma, ziyaretçilerin sübjektif normlarının, çevre dostu davranışlar sergileme intimalini etkileyebileceğini ortaya koymaktadır. Yadav ve Pathak (2017) 620 katılımcının verdiği cevaplara dayanarak, sübjektif normların bireylerin çevre dostu bir ürün satın almalarında etkili olduğunu göstermiştir. Yukarıda bahsedilen çalışmalar, sübjektif normlarla bireylerin davranışları arasında bir ilişki olduğunu kanıtlayabilir. Kişisel normlar, bu çalışmada gözlemlenmeyen ancak çevre dostu davranışların güçlü öngördürücülerinden biridir. Schwartz (1977), kişisel normların, bireyin ahlaki sorumluluklarını içsel değerler yoluyla yönlendirerek, var olan iyi / kötü ve doğru / yanlış algılarımızı değiştirdiğini belirmiştir. Mehmetoğlu (2010), kişisel normların sadece bireylerin günlük davranışlarında değil, aynı zamanda turizmle ilgili faaliyetleri sırasında da çevrenin yararı için gösterdikleri 
davranışlarında da etkili olduğunu ifade etmektedir. Bu çalışmada ise, daha önceki çalışmaların aksine (Chen ve Chai, 2010; Mehmetoğlu, 2010), kişisel normların çevre dostu davranışlar üzerinde bir etkisi olmadığını ortaya koymaktadır.

Literatürde çevresel endişenin kişilerin, çevre problemlerine yönelik davranışsal uygulamalarını motive ettiğini ve tüketicilerin satın almaya yönelik karar verme süreçlerini etkileyen faktörlerin başında geldiğini birçok çalışma bulunmaktadır (Mostafa, 2007; Mostafa, 2009; Lee ve diğ., 2014; Yadav ve Pathak, 2016). Bu çalışma rekreasyoncuların çevresel endişe düzeylerinin çevre dostu davranış göstermelerine etki etmediğini yani Kapadokya'da balona binen ziyaretçilerinin çevresel sorunlara karşı endişe duymadıkları ve bunun da davranışlarına yansımadığını göstermiştir. Tabi ki bu durum literatürdeki birçok çalışma ile çelişse de Göreme Milli Park'ında özellikle balon etkinliğine katılan ziyaretçiler için bu tür bir sonucun çıkması literatüre katkı anlamında değerlidir. Alanın doğal bir destinasyon olmasının yanında, farklı bir yanının bulunması sonraki çalışmalarda alana gelen ziyaretçilerin karakter olarak analiz edilmesini gerekli kılabilir.

Yer tutumu, doğal bir kaynağa yönelik duygusal bir bağ oluşturan veya mevcut bağı zenginleştiren bir olgudur (Vaske ve Kobrin, 2001:17). Literatürde bireylerin sahip olduğu bu algının sıklıkla ziyaret edilen yerlerde daha fazla görüldüğünü belirtilmiştir. Yani bu algının kazanılması ve bu bağ sayesinde insanların sıklıkla gittikleri bu yerlerde çevreyi korumaya yönelik davranışlar sergileyeceği öngörülmektedir (Kyle ve diğ., 2013; Brownlee ve diğ., 2015). Ancak bu çalışmada yer tutumunun çevre dostu davranışlar sergilemeye bir etkisinin olmadığı sonucuna ulaşılmıştır. Bu farklılığın nedeni Kapadokya'ya gelen ve balona binen turistlerin büyük çoğunluğunun uzak doğulu olması ve uzak ülkelerden gelmesi olabilir. Dolayısıyla ziyaret tekrarı yer tutumu algısı için çok önemli olduğundan ve Kapadokya için ziyaret sıklığı da az olduğundan bu sonuç beklenen bir durumdur.

Çevre dostu davranış, çevreci satın alma davranışlarındaki değişikliklerin \% 28,6'sını açıklayabilir. Bağımlı değişkenin bağımlı değişkene katkısı pozitif ve istatistiksel olarak anlamlı bulunmuştur. İnsanların günlük yaşamlarında çevreye ilişkin algıları, çevreye zarar veren uygulamaların farkındalığı ve bununla ilgili endişeleri yaşam tarzlarında ve satın alma davranışlarında görülebilir. Araştırmaya göre, rekreasyoncuların günlük yaşamlarında çevresel sorunlara ilişkin tutum ve algıları sadece soyut kalmamaktadır. Rekreasyoncular bunu harekete dönüştürerek satın alma şeklinde de gerçekleştirmektedirler. Özellikle de çevre dostu ürünlere yönelik satın alımlar yapmaları, bunu rutin hale getirdikleri, gıda veya günlük ihtiyaçların yanında bu satım alımları, örneğin; turizm organizasyonu içindeki kullanımlarında da sergiledikleri anlaşılmıştır.

Willuweit (2009) yapmış olduğu çalışmada, ziyaretçilerin özellikle ekolojik kaynaklarla çevrelenmiş doğaya dayalı destinasyonlara gittikten sonra çevre dostu davranışlarını geliştirdiğini vurgulamıştır. Bu durum, ziyaret veya gezi sırasında da görülebilir. Yazar bu nedenle bu etkileşimlerin çevresel davranışı artıracağını ve çevreye zarar vermenin önlenebileceğini belirtmiştir.

Çevre ve çevre kaynakları turizm sektörü için son derece önemlidir, ancak çevre sorunlarına karşı önlem almak artık devletlere ve özel sektöre ait işletmelere özgü bir endişe olmaktan çıkmıştır. Bireylerin de bu sorunları gidermek için sorumluluklarını yerine getirmeleri gerekmektedir. Bu sorun ancak kolektif bir davranış göstererek çözülebilir. İnsanları seyahat planlarında bu tür doğa temelli yerlere yönlendirebilir ve buradaki bir etkinliğe katılırlarsa, içinde yaşadığımız dünyada neler olduğunu görme 
fırsatı bulabilirler. Bu, ziyaretçilerin çevreye duyarlıı̆ını artırabilir. Ziyaretçiler mevcut sorunlara şahit olurlarsa, bu sorunları önlemeye yönelik bir tutum ve davranış sergileyebilirler. Dolayısıyla, doğa odaklı turlara katılımın öne çıkarılması ve desteklenmesi önemlidir.

Bu çalışmada, çevreci satın alma darvanışı gösterme eğilimi de bir diğer araştırma konusudur. Çalışmada bazı sınırlamalardan bulunmaktadır. Bunlardan en önemlisi, Göreme Milli Park'ının araştırma alanı ve balon etkinliğininde etkinlik olarak seçilmesidir. Bu çalışmanın kapsamını farklı sahaları kapsayacak şekilde genişletmek genellemeler yapabilmek için çok önemlidir. Bu amaçla hipotezler, orman alanları, doğal koruma alanları, vahşi yaşam alanları, göl ziyaretleri veya kuş gözlem turları gibi doğaya bağlı ortamlarda test edilebilir. Katılımcılar Göreme Milli Park'ına gelen ziyaretçilerdir ve bu nedenle bulguları diğer coğrafi bölgelere yaygınlaştırmak oldukça zordur. Ayrıca, çevre dostu davranışları etkilemesi muhtemel bazı yönlerin (çevre ile ilgili bilgi, çevre bilinci, çevreci tüketici vb.) dahil edilmesinin araştırmanın daha ayrıntılı bulgulara ulaşmasına imkan sağlayabileceği söylenebilir.

\section{Kaynakça}

Ajzen, I. (1991), 'The Theory Planned Behavior', Organizational Behavior And Human Decision Processes 50, ss.179-211.

Ali, F.; Amin, M. ve Cobanoglu, C. (2015), 'An Integrated Model of Service Experience, Emotions, Satisfaction, and Price Acceptance: An Empirical Analysis in the Chinese Hospitality Industry', Journal of Hospitality Marketing \& Management, 00, ss:1-27.

Ali, F.; Ryu, K. ve Hussain, K. (2016), 'Creative tourists' experience, memories, satisfaction and behavioural intentions', Journal of Travel and Tourism Marketing, 33(1), ss.85-100.

Arni, A.G. ve Khairil, W.A. (2013), 'Promoting Collaboration Between Local Community and Park Management Towards Sustainable Outdoor Recreation', Procedia Social and Behavioral Sciences, 91, ss.57-65.

Atay, L. ve Dilek, S. E. (2013), 'Konaklama İşletmelerinde Yeşil Pazarlama Uygulamaları: İbis Otel Örneği', Süleyman Demirel Üniversitesi, İktisadi ve İari Bilimler Fakültesi Dergisi, C.18, S.1, ss. 203-219.

Bagozzi, R. P. ve Yi, Y. (1988), 'On the Evaluation of Structural Equation Models', Journal of the Academy of Marketing Science, 16(1), 74-94.

Ballantyne, R.; Packer, J. ve Hughes, K. (2008), 'Environmental Awareness, Interests and Motives of Botanic Gardens Visitors: Implications for Interpretive Practice', Tourism Management, no: 29, ss. 439-444.

Bell, S.; Tyrvainen, L.; Seivanen, T.; Probstl, U. ve Simpson, M. (2007), 'Outdoor Recreation and Nature Tourism: A European Perspective', Living Reviews in Landscape Research, 1, 2.

Bricker, K. S. ve Kerstetter, D. L. (2000), 'Level of Specialization and Place Attachment: An Exploratory Study of Whitewater Recreationists', Leisure Sciences, 22(4), pp:233-257.

Brownlee, M. (2012), 'Nature-Based Recreationists' Perceptions of Climate Change and Attitudes Towards Climate Change Mitigation in Natural Environments', Doctoral Dissertation, In Partial Fulfillment of the Requirements for the Degree Doctor of Philosophy Parks, Recreation and Tourism Management Clemson University.

Brownlee, M. T. J.; Hallo, J. C.; Moore, D. D.; Powel, R. B. ve Wright, B. A. (2014), 'Attitudes toward Water Conservation: The Influence of Site-Specific Factors and 
Beliefs in Climate Change', Society and Natural Resources, 27, ss. 964-982, Taylor \& Francis Group.

Brownlee, M. T. J.; Hallo, J. C.; Jodice, L. W.; Moore, D. D.; Powel, R. B. ve Wright B. A. (2015), 'Place Attachment and Marine Recreationist's Attitudes toward Offshore Wind Energy Development', Journal of Leisure Research, Vol:47, no:2, ss. 263-284.

Budruk, M.; Thomas, H. ve Tyrrel, T. (2009), 'Urban Green Spaces: A Study of Place Attachment and Environmental Attitudes in India', Society and Natural Resources, 22, ss. 824-839.

Buhalis, D. ve Amaranggana, A. (2014), 'Smart Tourism Destinations', Information and Communication Technologies in Tourism, ss.553-564

Carranza, R.; Diaz, E. ve Martin, D. (2018), 'The Influence of Quality on Satisfaction and Customer Loyalty with an Importance-Performance Map Analysis: Exploring the Mediating Role of Trust', Journal of Hospitality and Tourism Technology, Vol. 9 Issue: 3, ss.380-396.

Chan R. Y. K. ve Lau L. B. Y. (2002), 'Explaining Green Purchasing Behavior', Journal of International Consumer Marketing, 14:2-3, ss. 9-40.

Chen, T. B. ve Chai, L. T. (2010), 'Attitude towards the Environment and Green Products: Consumers's Perspective', Management Science and Engineering, Vol. 4, No. 2, ss. 27-39.

Chin, Wynne W.; Peterson, R. A. ve Brown, S. P. (2008), 'Structural Equation Modeling in Marketing: Some Practical Reminders', The Journal of Marketing Theory and Practice, vol. 16, no. 4, ss. 287-298.

Chiu, H.Y.T.; Lee, W.I. ve Chen, T.H. (2014), 'Environmentally Responsible Behaviour in Ecotourism: Antecedents and Implications', Tourism Management, 40, ss. 321-329.

Conner, M. ve Armitage, C. J. (1998), 'Extending the Theory of Planned Behavior: A Review and Avenues for Further Research', Journal of Applied Social Psychology, 28, 15,ss. 1429-1464.

Crouch, G. I.; Devinney, T. M.; Dolnicar, S.; Huybers, T.; Louviere, J. ve Oppewal, H. (2005), 'New Horses for Old Courses: Questioning the Limitations of Sustainable Tourism to Supply-Driven Measures and the Nature-Based Contex', Paper presented at the ANZMAC, Fremantle, WA.

Davis, J. L.; Le, B. ve Coy, A. E. (2011), 'Building a Model of Commitment to the Natural Environment to Predict Ecological Behavior and Willingness to Sacrifice', Journal of Environmental Psychology, 31, ss. 257-265.

Diamantopoulos, A. ve Siguaw, J.A., (2006), 'Formative Versus Reflective Indicators in Organizational Measure Development: A Comparison and Empirical Illustration', Br. J. Econ. Manag., 17, ss. 263-282.

Dolnicar, S. (2006), 'Nature-Conserving Tourists: The Need for a Broader Perspective', Anatolia: An International Journal of Tourism and Hospitality, 17(2), ss. 235-255.

Dunlap, R. E.; Liere, K. D. V.; Mertig, A. G. ve Jones, R. E. (2000), 'Measuring Endorsement of the New Ecological Paradigm: A revised NEP scale', Journal of Social Issues, Vol:56, No:3, ss. 425-444.

Fahmy, R.; Bachtiar N.; Rahim, R. ve Malik M. (2015),'Measuring Student Perceptions to Personal Characters Building in Education: An Indonesian Case in Implementing New Curriculum in High School', Procedia - Social and Behavioral Sciences, 211, ss. $851-858$.

Fornell, C. ve Larcker, D.F. (1981), 'Evaluating Structural Equation Models with Unobservable Variables and Measurement Error', Journal of Marketing Research, Vol. 18 No. 1, ss. 3950.

Hair, J. F.; Ringle, C. M. ve Sarstedt, M. (2011), 'PLS-SEM: Indeed a Silver Bullet', The Journal of Marketing Theory and Practice, Vol. 19 No. 2, ss. 139-152. 
Hair, J. F.; Sarstedt, M.; Hopkins, L. G. ve Kuppelwieser, V. (2014), 'Partial Least Squares Structural Equation Modeling (PLS-SEM): An Emerging Tool in Business Research', European Business Review, Vol. 26 No. 2, ss. 106-121.

Halpenny, E. A. (2010), 'Pro-Environmental Behaviours and Park Visitors: The Effect of Place Attachment', Journal of Environmental Psychology 30, ss. 409-421.

Hammitt, W. E.; Kyle, G. T. ve Oh, Chi-Ok (2009), 'Comparison of Place Bonding Models in Recreation Resource Management', Journal of Leisure Research, 41, 1, ss. 57-72.

Harland, P.; Staats, H. ve Wilke, H. A. M. (1999), 'Explaining Pro-Environmental Intention and Behavior by the Theory of Planned Behavior and Personal Norms', Journal of Applied Social Psychology, 29, 12, ss. 2505-2528.

Henseler, J.; Ringle, C. M. ve Sinkovics, R. (2009), 'The Use of Partial Least Squares Path Modeling in International Marketing', Advances in International Marketing, Vol. 20, ss. 277-319.

Henseler, J.; Ringle, C. M.; Sarstedt, M. (2015), 'A New Criterion for Assessing Discriminant Validity in Variance-Based Structural Equation Modeling', Journal of the Academy of Marketing Science, January, Volume 43, Issue 1, ss. 115135

Henseler, J.; Hubona, G. ve Ray, P.A.(2016), 'Using PLS Path Modeling in New Technology Research: Updated Guidelines', Ind. Manage. Data Syst., 116 (1), ss. $2-20$.

Hulland, J. (1999), 'Use of Partıal Least Squares (pls) in Strategıc Management Research: A Review of Four Recent Studies', Strategic Management Journal, 20, ss. 195-204.

Jarvis, C. B.; MacKenzie, S. B. ve Podsakoff, P.M. (2003), 'A Critical Review of Construct Indicators and Measurement Model Misspecification in Marketing and Consumer Research', Journal of Consumer Research,30(2), ss. 199-218

Kim, Y. ve Han H. (2010), 'Intention to Pay Conventional-Hotel Prices at a Green Hotel - a Modification of the Theory of Planned Behavior', Journal of Sustainable Tourism, Vol. 18, No. 8, ss. 997-1014, November.

Knetsch, J. L. ve Var, T. (1976), 'The Impacts of Tourism and Recreational Facility Development, The Tourist Review', Vol. 31 Issue: 4, ss. 5-10.

Korpela, K. M.; Ylen, M.; Tyrvainen, L. ve Silvennoinen, H. (2009), 'Stability of SelfReported Favourite Places and Place Attachment Over a 10-Month Period', Journal of Environmental Psychology, 29, ss. 95-100.

Kyle, G. T.; Absher, J. D. ve Graefe, A. R. (2003), 'The Moderating Role of Place Attachment on the Relationship Between Attitudes Towards Fees and Spending Preferences', Leisure Sciences, 25(1), ss. 33-50.

Kyle, G.; Graefe, A.; Manning, R. ve Bacon, J. (2004), 'Effects of Place Attachment on Users' Perceptions of Social and Environmental Conditions in a Natural Setting', Journal of Environmental Psychology, 24, ss. 213-225.

Lee, T. H.; Jan, F. H., ve Yang, C. C. (2013), 'Conceptualizing and Measuring Environmentally Responsible Behaviors From the Perspective of CommunityBased Tourists', Tourism Management, 36, ss. 454-468.

Lee, Y. K.; Kim, S.; Kim, M. S. ve Choi, J. G. (2014), 'Antecedents and Interrelationships of Three Types of Pro-Environmental Behavior', Journal of Business Research, 67, ss. 2097-2105.

Mansuroğlu, S. (2002), 'Akdeniz Üniversitesi Öğrencilerinin Serbest Zaman Özellikleri Ve Dış Mekân Rekreasyon Eğilimlerinin Belirlenmesi', Akdeniz Üniversitesi Ziraat Fakültesi Dergisi, 15(2), ss. 53-62.

Manzo, L. C. ve Perkins, D.D. (2006), 'Finding Common Ground: The Importance of Place Attachment to Community Participation and Planning', Journal of Planning Literature, Vol. 20, No. 4, ss. 335-350. 
Martin, D. S.; Ramamonjiarivelo, Z. ve Martin W. S. (2011), 'MEDTOUR: A Scale for Measuring Medical Tourism Intentions', Tourism Review, Vol. 66 Issue: 1/2, ss. 45-56.

Mehmetoğlu, M. (2010), 'Factors Influencing the Willingness to Behave Environmentally Friendly at Home and Holiday Settings', Scandinavian Journal of Hospitality and Tourism, 10(4), ss. 430-447.

Memon, A.H. ve Rahman, I. A. (2014), 'SEM-PLS Analysis of Inhibiting Factors of Cost Performance for Large Construction Projects in Malaysia: Perspective of Clients and Consultants', The Scientific World Journal, Volume Article ID 165158, 9 pages.

Miller, D.; Merrilees, B. ve Coghlan, A. (2015), 'Sustainable Urban Tourism: Understanding and Developing Visitor Pro-Environmental Behaviors', Journal of Sustainable Tourism, 23(1), ss. 26-46.

Minton, A. P. ve Rose, R. L. (1997), 'The Effects of Environmental Concern on Environmentally Friendly Consumer Behavior: An Exploratory Study', Journal of Business Research, 40, ss. 37-48.

Molina, M.; Francez, D.S.; Morena, F.A. ve Saura, I.G. (2018), ‘Development and Validation of a Formative Scale of Technological Advancement In Hotels from The Guest Perspective', Journal of Hospitality and Tourism Technology, 9(3), ss. 280-294.

Mostafa, M. M. (2007), 'Gender Differences in Egyptian Consumers' Green Purchase Behaviour: The Effects of Environmental Knowledge, Concernand Attitude', International Journal of Consumer Studies,31, ss. 220-229.

Mostafa, M. M. (2009), 'Shades of Green: A Psychographic Segmentation of the Green Consumer in Kuwait Using Self-Organizing Maps', Expert Systems with Applications, 36, ss. 11030-11038.

Mostafa, M. M. ve Al-Hamdi, M. (2016), 'Kuwaiti Consumers' Willingness to Pay for Environmental Protection in Failaka Island: A Contingent Valuation Analysis', Tourism Review, 71(3), ss. 219-233.

Park, H. S. (2000), 'Relationships Among Attitudes and Subjective Norms:Testing the Theory of Reasoned Action Across Cultures', Communication Studies, 51(2), ss. 162-175.

Rezaei, S. ve Ghodsi, S. S. (2014), 'Does Value Matters in Playing Online Game? An Empirical Study Among Massively Multiplayer Online Role-Playing Games (MMORPGs)', Computers in Human Behavior, Vol. 35, ss. 252-266.

Ringle, C.; Wende, S. ve Becker, J., (2015), 'SmartPLS3', www.smartpls.com (20.05.2019).

Rivera, M. A.; Murphy, K. S. ve Khalilzadeh, J. (2018), 'Globalization of Workforce: Pls Approach to Higher-Order Value Construct in A Study Abroad Context', Journal of Hospitality and Tourism Technology, 9(3), ss.314-337.

Rubright, H. L. (2014), 'Consumer Purchasing in Sustainable Tourism: Attraction Sustainability and Its Impact on Decision-Making, A Thesis Presented to the Faculty of the Department of the Graduate School East Carolina University, In Partial Fulfillment of the Requirements for the Degree M.S Sustainable Tourism.

Sapihis, M.; Loh S. Y.; Roslani, A. C. ve Chinna, K. (2015), 'Participation Restriction in Cancer Survivors: A Cross-Cultural Adaptation and Psychometric Evaluation of Occupational Gap Questionnaire', JurnalTeknologi (Science \& Engineering) 77:33, ss. 49-57.

Schwartz, S. H. (1977), 'Normative Influences On Altruism', https://www.researchgate.net/publication/319507233 NORMATIVE INFLUENC ES ON ALTRUISM (10.04.2019).

Sie, L.; Phelan, K.V. ve Pegg, S. (2018), 'The Inter Relationships Between SelfDetermined Motivations, Memorable Experiences and Overall Satisfaction: A 
Case of Older Australian Educational Tourists', Journal of Hospitality and Tourism Technology, 9(3), ss. 354-379.

Song, H.J.; Lee, C. K.; Kang, S. K. ve Boo, S. J. (2012), 'The Effect of Environmentally Friendly Perceptions on Festival Visitors' Decision-Making Process Using An Extended Model of Goal-Directed Behavior', Tourism Management, 33, ss. 1417-1428.

Stacie, P.; Detmar, S. ve Arun, R.(200), 'Specifying Formative Constructs in Information Systems Research', MIS Q., 31, ss. 623-656.

Stern, P. C. (2000), 'Toward a Coherent Theory of Environmentally Significant Behavior', Journal of Social Issues, 56(3), ss. 407-424.

Tenenhaus, M.; Vinzi, V.; Chatelin, Y. M. ve Lauro, C. (2005), 'PLS Path Modelling', Computational Statistics and Data Analysis, 48(1), ss. 159-205.

Tonge, J.; Ryan, M. M.; Moore, S. A. ve Beckley, L. E. (2015), 'The Effect of Place Attachment on Pro-Environment Behavioral Intentions of Visitors to Coastal Natural Area Tourist Destinations', Journal of Travel Research, 54 (6), ss. 730743.

Vaske, J. J. ve Kobrin, K. C. (2001), 'Place Attachment and Environmentally Responsible Behavior', The Journal of Environmental Education, 32(4), ss. 1621.

Williams, D. R.; Patterson M. E.; Roggenbuck, J. W. ve Watson A. E. (1992), 'Beyond the Commodity Metaphor: Examining Emotional and Symbolic Attachment to Place', Leisure Sciences, Volume 14, ss. 29-46.

Williams, D. R. ve Vaske, J. J. (2003), 'The Measurement of Place Attachment: Validity and Generaliz Ability of a Psychometric Approach', Forest Science, 49(6), ss. 830-840.

Willuweit, Lars (2009), 'Promoting Pro-Environmental Behavior An Investigation of the Cross-Cultural Environmental Behavior Patterns: The Case of Abu Dhabi', Thesis From The Department Of Human Geography, Stockholm University.

Yadav, R. ve Pathak, G. S. (2016), 'Young Consumers' Intention Towards Buying Green Products in Adeveloping Nation: Extending the Theory of Planned Behavior', Journal of Cleaner Production, 135, ss. 732-739.

Yadav, R. ve Pathak, G. S. (2017), 'Determinants of Consumers' Green Purchase Behavior in a Developing Nation: Applying and Extending the Theory of Planned Behavior', Ecological Economics, 134, ss. 114-122.

Yuzhanin, S. ve Fisher, D. (2016), 'The Efficacy of the Theory of Planned Behavior for Predicting Intentions to Choose a Travel Destination: A Review', Tourism Review, 71(2), ss. 135-147.

Zhang, Y.; Zhang, H. L.; Zhang, J. ve Cheng, S. (2014), 'Predicting Residents' ProEnvironmental Behaviors at Tourist Sites: The Role of Awareness of Disaster's Consequences, Values, and Place Attachment', Journal of Environment Psychology, 40, ss. 131-146.

Zhang, Y.; Zhang, J.; Ye, Y.; Wu, Q.; Jin, L. ve Zhang, H. (2016), Residents' Environmental Conservation Behaviors at Tourist Sites: Broadening the Norm Activation Framework by Adopting Environment Attachment', Sustainability, 8, 571, ss. 1-16. 